\title{
The Socio-Economic Benefits of Rural-Urban Migration: A Study in Foron District of Jos Plateau, Plateau State, Nigeria
}

\author{
Basil U. Eze \\ Department of Geography and Meteorology, Enugu State University of Science and Technology, Enugu State Nigeria
}

\begin{abstract}
This work looked at the socio-economic benefits of rural-urban migration in the Jos Plateau with focus on Foron district of Plateau state, North Central Nigeria. Adopting survey research design, household questionnaires were used to obtain data from 5 villages and 170 households that supplied information on 233 rural out-migrants. The results of the study were presented and analyzed using tables, graphs and Pearson Product Moment Correlation Coefficient ( $r P$ ). The results of the study shows a high rate of economic contact between migrants and their source regions as $92.27 \%$ of them visited home in the course of a year and majority of them for the purpose of bringing money home. $85.84 \%$ remitted money and over $70 \%$ remitted food stuffs and other provisions. $77.69 \%$ of the migrant-sending households confirm that their families have been better off as a result of remittances from migrants. It was equally found a decrease in frequency of monetary remittances with increasing period away from source region. This was found to be statistically significant. It is recommended a re-education and re-motivation of urbanites towards remitting steadfastly necessary resources back home to continue to maintain and improve the welfare of their rural households.
\end{abstract}

Keywords: Socio-economic, benefits, rural-urban, migration, Foron District

\section{Introduction}

It is evident that much migration from various parts of the world is circular. People continue to maintain strong links with their areas of origin and destination. Migration follows a variety of patterns which include urban-urban, urban-rural, rural-rural and rural-urban. This study is centred on ruralurban migration which constitutes one of the currents of internal migration in Nigeria and elsewhere. As Eze (2014) puts it, rural-urban migration involves the movement of people from rural areas to urban areas on permanent or semipermanent basis. It is a type of migratory movement in which the motive is not only to improve the movers' livelihood opportunities and welfare, but also the livelihood improvement of those left behind in the rural area. (Eze and Mobosi, 2015).

Recently, migrants' remittances and income multipliers they create according to World Bank (2005), are becoming critical resources for the sustenance strategies of receiving households as well as agents of regional and national development. The cost benefit calculation of rural-urban migration has been an issue of debate. Some have held that rural-urban migration rob villagers of human and material resources while the alternate school argue that surplus cash from urban areas in terms of remittances help in the development of social and infrastructural amenities in the rural areas. It is argued according to Fadayomi (1988) that each current of migration is associated with a contemporary counter current in forms of rural development including family support.

Generally, rural-urban migration is a function of several variables which include income, socio-economic variables, gender factors, age, education, etc (Hugo, 1998). It is seen that migrants may exert an impact on rural sending areas through some channels of influence among which include visits and remittances in cash and kind. Aligning with the pros of rural-urban migration, Ajaero (2013), identified migration as a livelihood strategy utilized by the poor especially rural dwellers. This paper, therefore, identifies the socio-economic benefits of rural-urban migration in the Foron district of Jos Plateau and so contributes to buttressing the positive values of migration not only in the district under study but in rural Nigeria generally.

\section{The Study Area}

Foron district is one of the districts in BarkinLadi local government area of Plateau state. Their villages lay scattered within the hills south -west of Bauchi . It lies approximately between latitudes 9 9 39 "and 9 9050" North and longitudes $8^{\circ} 54^{\prime \prime}$ and $9^{\circ} 9^{\prime \prime}$ East. The general topography of the area is that of an extensive plain interspersed by rock outcrops, hills and stone debris which litter the entire surface. The district is on average elevation of 1500 metres and covers a land area of about 850 sq. kms. The district, like most rural areas of Nigeria is devoid of adequate socio-economic opportunities and infrastructural facilities and so exports its educated youths to urban areas, which justifies its being chosen for this study. 


\section{International Journal of Science and Research (IJSR) \\ ISSN (Online): 2319-7064}

Index Copernicus Value (2013): 6.14 | Impact Factor (2014): 5.611

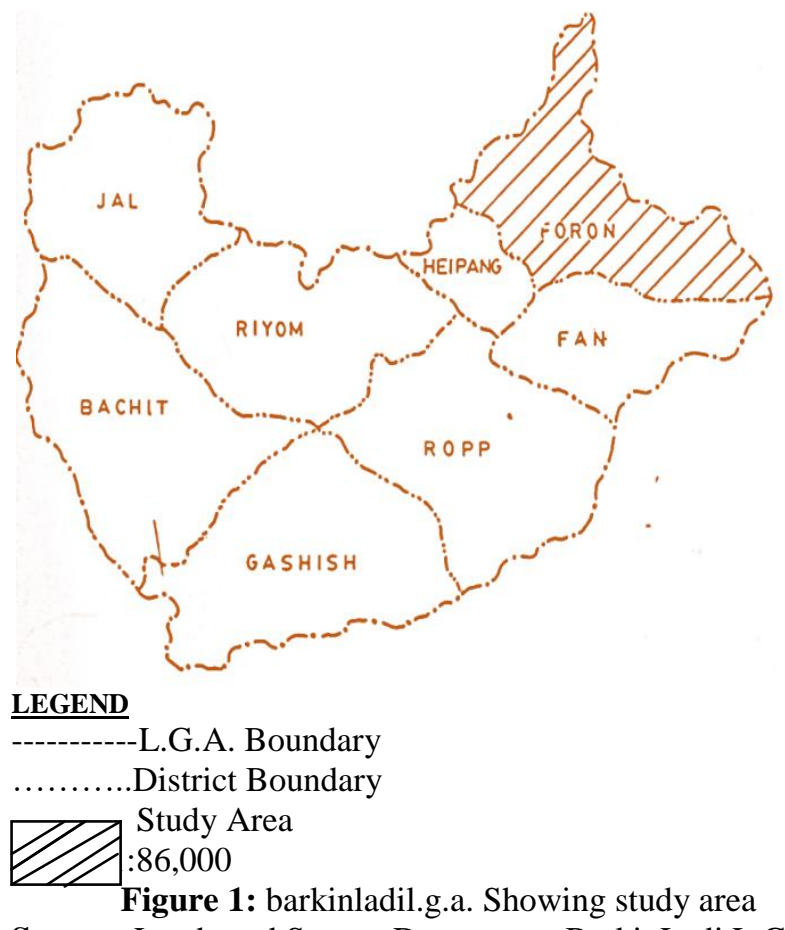

Source: Lands and Survey Department BarkinLadi L.G.A.

\section{Methodology}

A survey research design was employed. This involved the use of household questionnaire which was used to get information from household heads on the out-migrants from their households.

A two-stage sampling was used. At the first stage, five villages representing one-third of the total number of villages (15) in the district were selected. The villages: Bisichi, MaiIdon-Toro, Sabon Gida and BakinKogi were randomly selected to ensure objectivity in their evaluation while Zabot, for being the headquarters of the district was purposefully chosen.

Systematic sampling was employed in the second stage of the sampling method which involved the selection of households. This was considered good since there were no out-migrants in some households; it was thus easier for the next household to be chosen in place of such households without out-migrants in them. Systematic sampling was also considered good, since the object of study, the out-migrants, were studied without reference to the geographical location of various households which provided the information about them in each village of origin. On the whole, a total of 170 household heads were interviewed and information was collected on 233 out-migrants. The data was presented and analyzed using tables, charts and graphs. The inferential statistics used is Pearson Product moment Correlation Coefficient $\left({ }^{\mathrm{T}} \mathrm{P}\right)$ which model is thus:

$$
\begin{gathered}
r_{P}=E x y-\frac{(E x)(E y)}{n}--------- \\
\sqrt{\left[\sum x^{2}-\frac{\left(\sum x\right)^{2}}{n}\right]\left[\sum y^{2}-\frac{\left(\sum y\right)^{2}}{n}\right]}
\end{gathered}
$$

Where $x$ and $y$ are the two sets of observation

\section{Presentation of Results}

\section{Channels of Impact on Rural Source Region}

This section looks at the means of out-migrants impacts on the home/source region as defined by their visits, period away from source region, remittances in cash and gifts/presents.

\section{Frequency of visits}

Table 1: Distribution of Out-migrants by frequency of Visits

\begin{tabular}{|c|c|c|}
\hline Frequency[per year] & Number & $\%$ \\
\hline Never & 18 & 7.73 \\
\hline $1-3$ & 96 & 41.20 \\
\hline $3-5$ & 58 & 24.86 \\
\hline $6-8$ & 37 & 15.89 \\
\hline $9-12$ & 19 & 8.15 \\
\hline $13+$ & 5 & 2.14 \\
\hline Total & 233 & 100 \\
\hline
\end{tabular}

Source: Author's Fieldwork,

Most of the out-migrants, $92.27 \%$, as table 1 shows, make visit to their homes in the course of a year; 96 out-migrants representing $41.2 \%$ of the total, visit home between 1 to 2 times Per year. Only a relatively small number, 18, representing $7.73 \%$ of the out-migrants never visit home in the course of one year; the rest [51.07\%], visited more than 2 times.

\section{Distribution of Migrants by period away from Source region}

Table 2: Distribution of Out-migrants by period away from source region

\begin{tabular}{|c|c|c|}
\hline Period away (in years) & Number & $\%$ \\
\hline $1-3$ & 68 & 29.43 \\
$4-6$ & 60 & 25.75 \\
$7-9$ & 30 & 12.87 \\
$10-12$ & 36 & 15.45 \\
$13+$ & 39 & 16.73 \\
\hline Total & 233 & 100 \\
\hline
\end{tabular}

Source: Author's Fieldwork.

Table 2 indicates that $29.43 \%$ of the out-migrants, a slight majority, have spent between 1-3 years away from home. There is generally, a decrease in the number of out-migrants with increase in years; this can be attributed to return migration.

\section{Purpose of Home Visits}

Table 3: Distribution of Out-migrants by Purpose of Home

\begin{tabular}{|c|c|c|}
\multicolumn{3}{c}{ Visits } \\
\hline Purpose of Home Visit & Number & $\%$ \\
\hline See about family health/welfare & 202 & 86.69 \\
Bring Money & 181 & 77.82 \\
Supervise project/investment & 32 & 13.73 \\
Others (launching, marriage, festivals) & 23 & 9.87 \\
\hline & & $188.11^{*}$ \\
\hline
\end{tabular}

Source: Author's Fieldwork.

* Total percentage exceeds $100 \%$ because of multiple responses. 


\section{International Journal of Science and Research (IJSR) \\ ISSN (Online): 2319-7064 \\ Index Copernicus Value (2013): 6.14 | Impact Factor (2014): 5.611}

Table 3 shows that most of the out-migrants visit home to see to the social and economic well-being of the household.

\section{Remittances to Source Region by Out-migrants}

Table 4: Made remittances in cash since the past 12 months

\begin{tabular}{|c|c|c|}
\hline & Number & $\%$ \\
\hline Never remitted & 33 & 14.16 \\
Remitted & 200 & 85.84 \\
\hline Total & $\mathbf{2 3 3}$ & $\mathbf{1 0 0}$ \\
\hline
\end{tabular}

Source: Author's Fieldwork

According to table 4, 85.84\% of the Out-migrants have remitted various sums of money home since the past 12 months. Only $14.16 \%$ did not remit.

Table 5: Remittances in gifts and presents

\begin{tabular}{|l|l|l|}
\hline Presents & Number & $\%$ \\
\hline Nill & 21 & 9.01 \\
Foodstuffs & 93 & 39.91 \\
Provisions & 169 & 72.53 \\
\hline Total & & $121.45^{*}$ \\
\hline
\end{tabular}

Source: Author's Fieldwork.

* Total percentage exceeds $100 \%$ because of multiple responses.

Table 5 illustrates that besides remittances in cash shown in table 4, most of the out-migrants make remittances in gifts and presents.

The high proportion of out-migrants who visit home and make remittances of money and other goods in the course of a year is evidence of strong economic and livelihood impact on their source region.

Table 6: Uses of monetary remittances

\begin{tabular}{|c|c|c|}
\hline Uses of money & Number & $\%$ \\
\hline Healthcare and foodstuffs & 115 & 67.47 \\
\hline Farming & 32 & 18.82 \\
\hline School fees & 51 & 30.00 \\
\hline Others & 8 & 4.70 \\
\hline Total & & $\mathbf{1 2 0 . 9 9 *}$ \\
\hline
\end{tabular}

Source: Author's Fieldwork

* Total percentage exceeds $100 \%$ because of multiple responses.

As table 6 shows, a high proportion of money sent is used in maintaining the wellbeing of the family through healthcare and foodstuffs. The rest went into farming, school fees and other expenses.

\section{Contributions to Family Since Leaving Home}

Table 7: Distribution of Out-migrants by Contributions to Family since leaving home

\begin{tabular}{|c|c|c|}
\hline Contributions & Number & $\%$ \\
\hline $\begin{array}{c}\text { Training of children/relatives in school and other } \\
\text { areas }\end{array}$ & 134 & 31.75 \\
\hline Always come to the aid of family when needed & 153 & 65.66 \\
\hline Nil & 6 & 2.57 \\
\hline Total & & $158.77 *$ \\
\hline
\end{tabular}

Source: Author's Fieldwork
* Total percentage exceeds $100 \%$ because of multiple responses.

Table 7 shows that only $2.5 \%$ of the out-migrants have not made any contributions as listed since leaving home. The rest have made as the table indicates.

\section{Condition of the households since the out-migrants left home}

Of the sampled households, 38\% representing $22.35 \%$, maintained that there has not been any improvement in their standard of living or wellbeing since their child or relative out-migrated while 132 households representing $77.65 \%$ agreed that their families have been better off, some holding that the out-migrants have been their main source of sustenance.

\section{Statistical Analysis}

A statistical test was conducted to find out how period away from home affects links/contacts with the source region through monetary remittances. To this, the following hypothesis was formulated:

Ho: There is no significant relationship between period away from source region and frequency of monetary remittances.

The Pearson Product moment correlation coefficient $(r p)$ was employed to test the hypothesis. This is to show the extent of relationship between period one has stayed away from home and frequency of monetary remittances which also indicates the frequency of contacts or links with source region. The result of the test showed an $r p$ negative value of -0.73 (a strong negative relationship) which means that as period away from home increases, the frequency of monetary remittances decreases which equally implies a reduction in economic links with home. Employing the coefficient of determination $(r p)$, a value of 0.5329 was got which means that $53.29 \%$ variation in remittances can be attributed to variation in the length of period away from home. The remaining $46.71 \%$ variation depends on other factors. To test whether the relationship is a random occurrence or significant, a t-test was employed. The result showed that the computed t-value at 16.18 is greater than the theoretical at 0.05 and 0.01 levels of significance respectively. The null hypothesis is therefore, rejected. This implies that the relationship between period away from source region and frequency of monetary remittances is statistically significant. This also implies negative impact on the livelihood of families at home region.

\section{Discussion Of Results}

Among the channels through which migrants exert impact on their home origins are by their absence, by visits and remittances in cash and goods. The findings of this study show a high rate of economic contacts between the migrants and their source region as $92.27 \%$ of the migrants visited home in the course of a year and majority of them for the purpose of looking after family wellbeing. 85.84\% remitted money, over $70 \%$ remitted foodstuffs and other provisions. These findings align with that of Ajaero (2013) study in southeastern Nigeria where over $70 \%$ of the migrants sending households received remittances. This is equally 


\section{International Journal of Science and Research (IJSR) \\ ISSN (Online): 2319-7064 \\ Index Copernicus Value (2013): 6.14 | Impact Factor (2014): 5.611}

corroborated by Eze (2014) study in Nsukka region of southeastern Nigeria where it was found that $86.3 \%$ of the migrants remitted money home. These findings are equally in conformity with the findings of Fadayomi (1988) and findings of Caldwell as cited by Eze (2014), who in his study of rural-urban migration in Ghana concluded that the strongest contacts which the migrants maintain with the village are his or her visits and the transfer of money, goods, and consumables to their homes. These monies sent home were used for healthcare, foodstuffs, schooling and farming among others. This is also in agreement with previous studies as Eze (2014) citing Adepoju, asserted that remittances sent by migrants for general maintenance is of great importance to individual households who would have been poorer but for this close economic tie with their urban relatives. $77.69 \%$ of the migrants sending household in this study confirm that their families have been better off, some holding that the out-migrants have been their main source of sustenance. This then implies that the remittance system has stimulated a higher standard of living for many rural families in the study area as elsewhere.

This study found a negative relationship between period away from source region and volume of monetary remittances. Descriptive analysis of the study lends credence to this as it is found that there were 33 out-migrants representing $14.16 \%$ of the out-migrants as shown in table 4 who have not remitted money home since the past 12 months. Further investigation on the personal and other social characteristics of these out-migrants showed that 21 of them representing $63.63 \%$ of out-migrants in this group, have between 3-10 children and above all staying at the destination area and 28 out-migrants representing $84.84 \%$ in this group have been away from home for a period lasting between 4 to 13years and above. Thus one could suggest, first, that their not making any remittances home could be as a result of their large family sizes which spare them with no extra money to send home; second, that this could be as a result of the long period this people have spent away from home as this study have found a negative relationship between period away from source region and the volume of monetary remittances. Confirming this, Amin as cited by Eze (2014) suggested that, "this (not sending remittances), may be symptomatic of the beginning of migrant's alienation from original roots ...." Also in this group are 5 out-migrants representing $15.15 \%$ who are not married and have no children but have stayed between 1-3 years in their various destinations; we may therefore, have in this group, some very recent migrants, some of whom are yet to settle down in their destination areas and perhaps according to Makinwa (1981), cannot afford to send money home.

\section{Conclusion}

It is clear that migrants impact positively on their home origins to bring about improved livelihood of both their source communities generally and the specific families they left behind. This impact is usually executed through the agencies of visitation and remittances in cash and kind. This study have shown that rural-urban migration in the study area has engendered rural-urban socio-economic links which is geared towards the livelihood improvement and wellbeing of the migrant-sending households and the entire source region. It is equally found that the longer one stayed away from home, the less the frequency of monetary remittances which will then negatively affect the economy of the home origin. So, remittances are crucial component of rural household income. It is recommended a development of a social vehicle of re-education and re-motivation of urbanites towards remitting steadfastly necessary resources back home to improve the welfare of their rural households as well as effect meaningful development of their communities (Eze, 2014).

\section{References}

[1] Ajaero, C.K (2013). "The Spatial Impacts of Rural-Urban Migration on Rural Livelihoods in Southeastern Geopolitical Zone of Nigeria. Unpublished Ph.D. Thesis. Dept of Geography University of Nigeria Nsukka.

[2] Eze, B.U (2014). Appraisal of the Impacts of Rural-urban Migration on the livelihoods of rural households in Nsukka Region, Southeastern Nigeria. An unpublished Ph.D thesis. Department of Geography and Meteorology, Enugu State University of Science and Technology, Enugu.

[3] Eze, B.U and Ikechukwu, A.M (2015). "Rural-Urban Migration and Household Livelihood Assets in Nsukka Region of Nigeria". International Journal of physical and Social Sciences. http://www.ijmra,us

[4] Fadayomi, T.O (1988): Rural Development and Migration in Nigeria: Impact of Eastern Zone of Bauchi State Agricultural Development Project. Institute of Social and Economic Research, Ibadan, Nigeria.

[5] Hugo, G. (1998). "Migration as a Survival Strategy. The Family Dimension of Migration. Population and Development Review, pp.8.

[6] Makinwa, P.K (1981). Internal Migration and Rural Development in Nigeria: Lessons from Bendel State. Heinemann, Ibadan.

[7] World Bank (2005): Global Development Finance. Mobilizing Finance and Managing Vulnerability, Washington D.C. World Bank. 